\title{
ENVIRONMENTAL GEOCHEMISTRY AND SUSTAINABLE DEVELOPMENT: CASE STUDIES FROM GREECE
}

\author{
Argyraki A. \\ National and Kapodistrian University of Athens, Faculty of Geology and Geoenvironment, \\ Panepistimiopolis Zographou, 158 76, Athens,argyraki@geol.uoa.gr
}

\begin{abstract}
The contribution of environmental geochemistry to sustainable development is discussed through the presentation of different case studies from Greece. The aim is to demonstrate the impact of geochemistry to a variety of societal and economic areas such as the sustainable exploitation of natural resources, the assessment of environmental problems within cities and the sustainable remediation of contaminated land. Several examples of completed and ongoing research are provided including a pre-mining survey in Skouries, Chalkidiki, a geochemical background study in an area of serpentine, agricultural soil in Atalanti, the urban soil geochemistry of Athens and the use of natural minerals as amendments for the remediation of contaminated land. The paper concludes with some facts on opportunities and obstacles to development in the field of environmental geochemistry in Greece under the current economic crisis conditions.
\end{abstract}

Keywords: baseline geochemistry, geochemical mapping, sustainable remediation, urban geochemistry, economic crisis.

\section{Пєрí $\eta \psi \eta$}

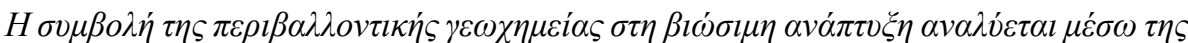

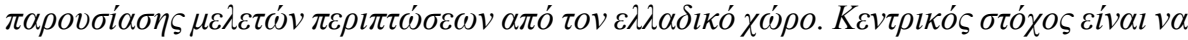

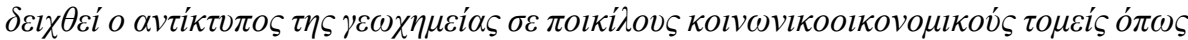

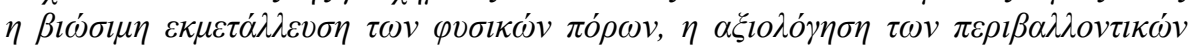

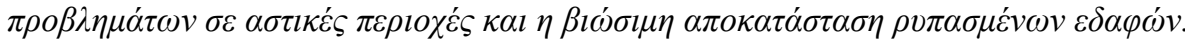

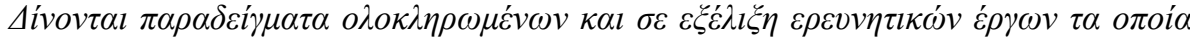

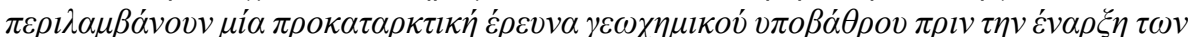

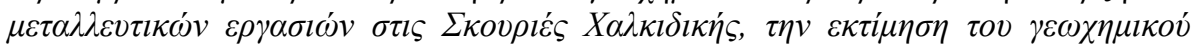

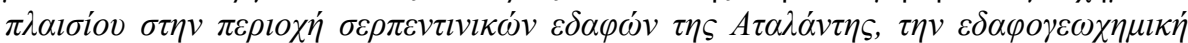

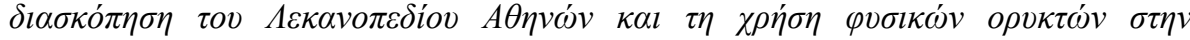

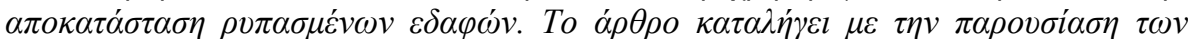

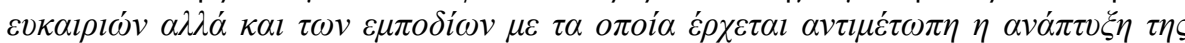

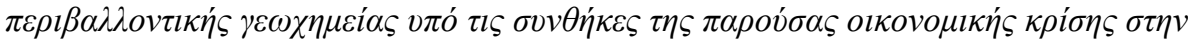
$E \lambda \lambda \dot{\alpha} \delta \alpha$.

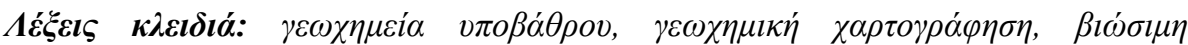

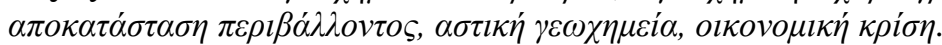

\section{Introduction}

Environmental geochemistry involves the study of the interaction and circulation of elements in the system lithosphere- hydrosphere- biosphere. It examines both natural and anthropogenic processes 
in the surface environment of our planet, thus contributing to the solution of a wide range of environmental pollution problems. Analytical developments as well as conceptual breakthroughs in recent years have resulted in great advancements and helped geochemical research to become a versatile scientific field covering the entire spectrum of earth sciences (Ludden et al., 2015). However, although applied research has a central role in environmental geochemistry, providing the evidence to enable decision-making, its social and economic impact is just starting to be recognized internationally. Environmental geochemistry has been evolved as a branch of applied geochemistry which is directly linked to the development of methods and techniques used for the detection of geochemical anomalies, a basic principle in the exploration of mineral deposits. As such, it is directly related to the evolution of human societies which intimately depends on the exploitation of natural resources.

In recent years, raised awareness of the resource limits brought the attention on the challenges of resource depletion and sustainability within the frame of global economy. An excellent review on the current and future availability of many natural resources in the context of sustainable development is provided by Sverdrup and Ragnarsdottir (2014). In their discussion they adopt the terminology of Alan Atkinson (Atkinson, 2008) who defines sustainable development as: "A directed process of continuous innovation and systemic change in the direction of sustainability" and sustainability as: "A set of conditions and trends in the given system that can continue indefinitely." They also state that sustainable development implies that there are quantifiable limits to physical consumption as well as to natural system acceptable damage and that growth and degrowth are continuously present in society, representing its relative positioning to the sustainability limits.

The present paper discusses the contribution of environmental geochemistry to sustainable development in Greece. In the middle of an economic crisis that lasts over five years, Greek geoscientists are faced with enormous challenges as they try to remain focused on their research while coping with low career prospects and salary cuts. Although there is no easy answer, this article contains some examples underlining the impact of environmental geochemistry to the sustainable development of the country and attempts to address the question what are the opportunities and obstacles to development in the field of study in Greece nowadays?

\section{Case studies demonstrating the impact of environmental geochemistry in sustainable development in Greece}

\subsection{A pre-mining geochemical baseline survey in the area of Skouries, Chalkidiki}

This research provided a unique opportunity to study a changing environment and gather pre-mining data before the start of exploitation of the Skouries porphyry $\mathrm{Cu}$-Au deposit at Kassandra mining district, north Greece. Pre-mining baseline characterization studies of unmined mineralized areas may be useful in serving the purposes of sustainable mining by providing a basis for detecting future environmental change and setting realistic remediation standards. This study defined the pre-mining signatures in soil, sediment and water of the mineralized watershed of Asprolakkas, adjoining to the porphyry copper deposit of Skouries (Fig.1).

The study area of approximately $2 \mathrm{~km}^{2}$ was densely forested and characterized by rough topography and high slopes. Local geology comprises metamorphic rocks of mica schist and gneiss. Parts of the study area were planned as mine tailing disposal areas and will be receiving waste originating from the future open pit mine at Skouries. Sixty five soil samples $(0-25 \mathrm{~cm}$ depth $)$ were collected on a $200 \mathrm{~m} \times 200 \mathrm{~m}$ regular grid covering the slopes of the creek. Nine water and stream sediment samples were also collected along the main stream of the catchment and at tributaries. Results of total analysis of soils indicated elevated mean concentrations of $\mathrm{Pb}\left(526 \mathrm{mg} \mathrm{kg}^{-1}\right), \mathrm{Zn}\left(350 \mathrm{mg} \mathrm{kg}^{-1}\right)$, As (165mg $\left.\mathrm{kg}^{-1}\right)$, Sb (13mg kg-1 $) \mathrm{Cd}\left(16 \mathrm{mg} \mathrm{kg}^{-1}\right)$, and $\mathrm{Mn}\left(1774 \mathrm{mg} \mathrm{kg}^{-1}\right)$. Acid base accounting indicated a positive net neutralization capacity of soil at the time of the study (Argyraki and Kelepertzis, 2012). 
Elevated levels of $\mathrm{Pb}\left(39-1812 \mathrm{mg} \mathrm{kg}^{-1}\right)$, Zn (73-2090mg kg-1), As (43-1136 mg kg-1), Mn (680$>10000 \mathrm{mg} \mathrm{kg}^{-1}$ ) and $\mathrm{Sb}\left(3-40 \mathrm{mg} \mathrm{kg}^{-1}\right)$ in stream sediment samples signified that sediments are a favorable sink for elements, which are introduced to the aquatic environment of the drainage system following chemical weathering of the existing sulphide mineralization (Kelepertzis et al., 2012). Mobility of selected heavy metals in stream sediment samples was investigated through the application of a 5-step sequential extraction procedure. Results showed that, despite the high total metal content, the majority of analyzed elements are mainly bound to relative immobile operationally defined geochemical phases of amorphous to poorly crystalline Fe and Mn oxides and the residual fraction.

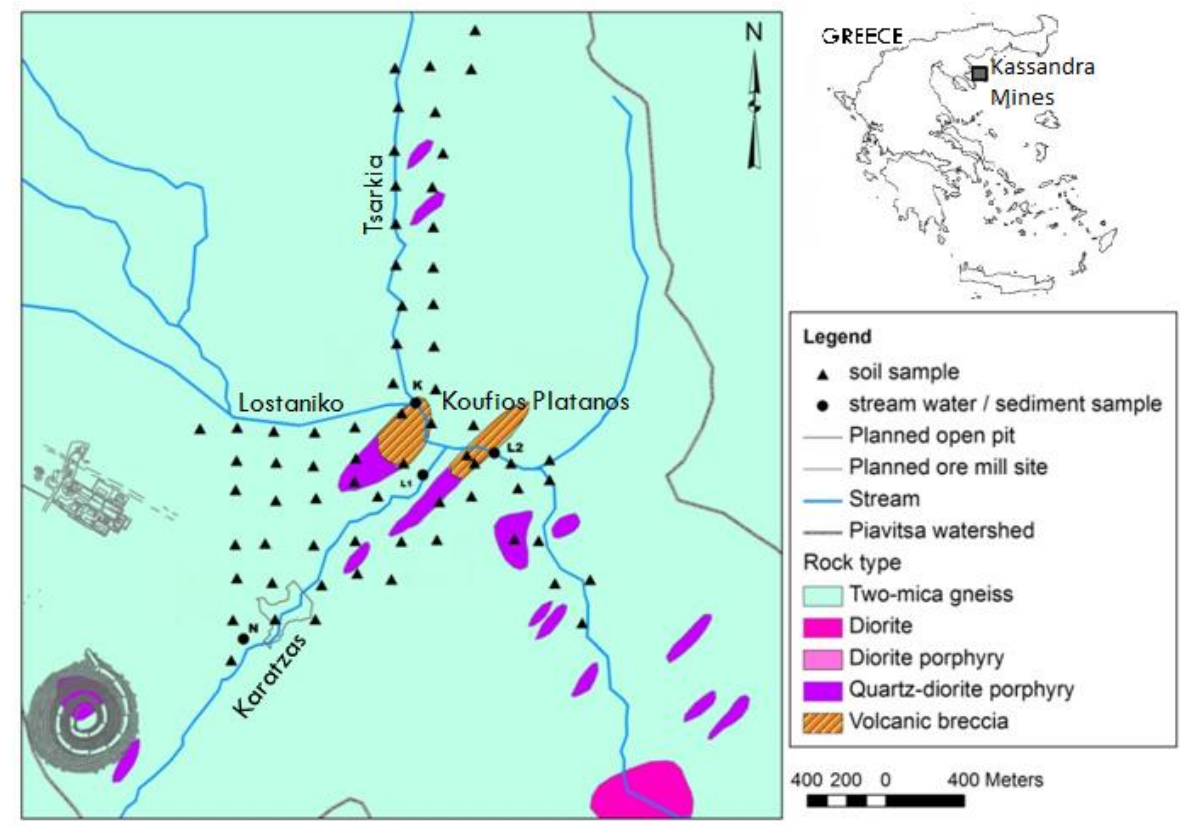

Figure 1 - Sampling locations in Skouries area.

Surface waters were predominantly near neutral to mildly alkaline and Eh data indicated moderate reducing conditions. Electrical Conductivity (EC) varied widely from 328 to $1669 \mu \mathrm{S} \mathrm{cm} \mathrm{cm}^{-1}$, indicating significant differences between the stream water ion content. The highest metal/ metalloid concentrations in water samples were measured for $\mathrm{Pb}\left(2-45 \mu \mathrm{g} \mathrm{l}^{-1}\right)$, Mn (5-106 $\left.\mu \mathrm{g} \mathrm{l}^{-1}\right)$ and As (4$141 \mu \mathrm{g}^{-1}$ ). Chemical elements exhibited a wide spatial and seasonal variation in stream water (Fig. 2). Hydrological conditions are important in modelling the element concentrations. Major ion content decreases in the wet period as a result of dilution owing to the heavy winter rainfall.

The methodology of this research was guided by exposure targets (water wells downstream supplying the surrounding villages with domestic water) and the mining development plan. The geochemical baseline established for soil was encompassed in the Environmental Impact Assessment submitted by the mining company and along with data on stream sediment and water quality provide an objective basis for setting realistic remediation targets in the future. 
April 08

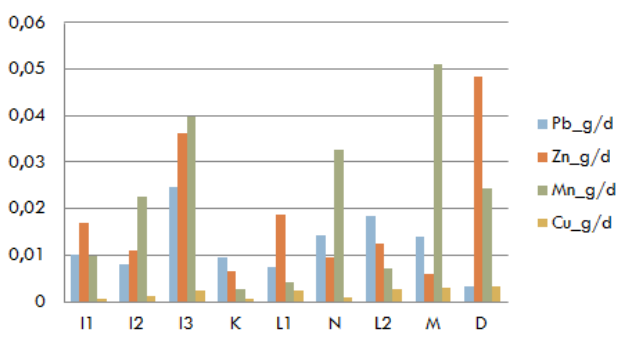

November 08

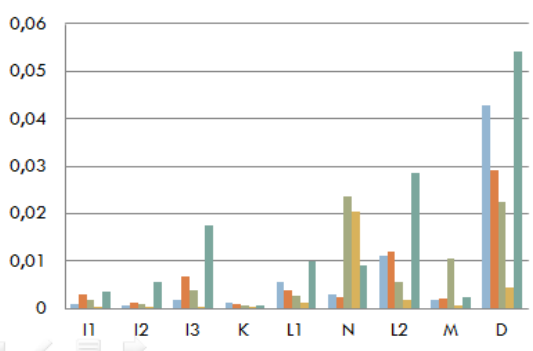

July 08
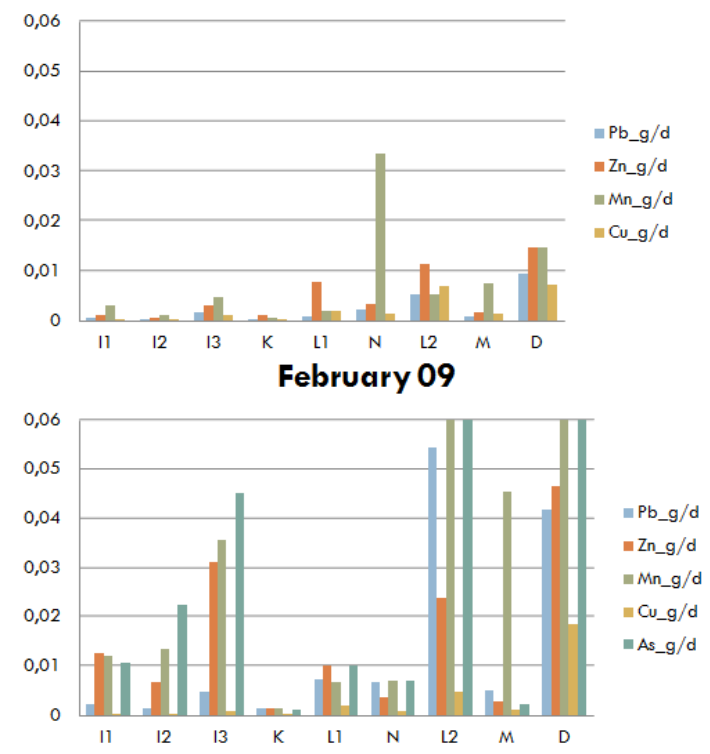

Figure 2 - Seasonal variation of metal loadings in stream water in Skouries area.

\subsection{Baseline geochemistry in the area of serpentine soils in Atalanti basin}

Naturally occurring high contents of $\mathrm{Cr}$ (III) in ultramafic rocks and serpentinites of ophiolite sequences may be oxidized and converted to toxic $\mathrm{Cr}(\mathrm{VI})$ by natural oxidants under certain favorable environmental conditions (Ball and Izbicki, 2004). In Greece, mafic and ultramafic rocks of ophiolithic sequences cover large areas and several recent publications on CrVI contaminated areas (e.g. Economou-Eliopoulos et al., 2011; Moraetis et al., 2012; Dermatas et al., 2012) have highlighted the need of establishing such baselines in order to provide an objective basis for decision making and selection of appropriate mitigation measures. Within this frame, a soil, groundwater and plant geochemical survey in the agricultural area of Atalanti, central Greece, has been performed in order to establish the local geochemical baseline of soil with respect to geogenic elements derived from the ultramafic rocks and to evaluate the impact of ultramafic rocks on soil and groundwater chemistry (Kanellopoulos et al., 2015).

The agricultural soil of Atalanti basin is affected by the physical and chemical weathering of mafic and ultramafic rocks outcropping in the surrounding mountainous area, giving rise to elevated concentrations of $\mathrm{Cr}, \mathrm{Ni}, \mathrm{Co}$ and other elements. It was found that the supply of material in the studied valley is mainly achieved through the drainage network. In uphill areas south of the basin influence of relatively unweathered ultramafic rocks on the mineralogy and geochemistry of soil is dominant giving rise to maximum concentrations of $\mathrm{Cr}\left(4290 \mathrm{mg} \mathrm{kg}^{-1}\right), \mathrm{Ni}\left(2730 \mathrm{mg} \mathrm{kg}^{-1}\right)$, and Co (250 $\mathrm{mg} \mathrm{kg}^{-1}$ ), in soil (Fig. 3). The Ni hyperaccumulator species Alyssum chalcidicum was identified only in these areas, in close proximity to unweathered peridotite rock. Different mobilization processes give rise to relatively high groundwater concentrations of $\mathrm{Cr}$ (up to $25 \mu \mathrm{g} \mathrm{l}^{-1}$ ) and almost no detectable concentrations of $\mathrm{Ni}$ in the alluvial aquifer of Atalanti plain. The relatively higher $\mathrm{Cr}$ mobilization and groundwater enrichment in the central axis of the alluvial aquifer is related to the increased thickness of sediment column and groundwater flow, allowing for effective water-soilrock interaction and release into the water. Nickel is effectively retained in the solid phase under the prevailing alkaline soil conditions and has minimal concentrations in groundwater. The results of this study can be utilized in future research at areas of similar geology and climatic conditions by providing an objective basis for setting realistic threshold values for pollution assessment and remediation (Kanellopoulos et al., 2015). 

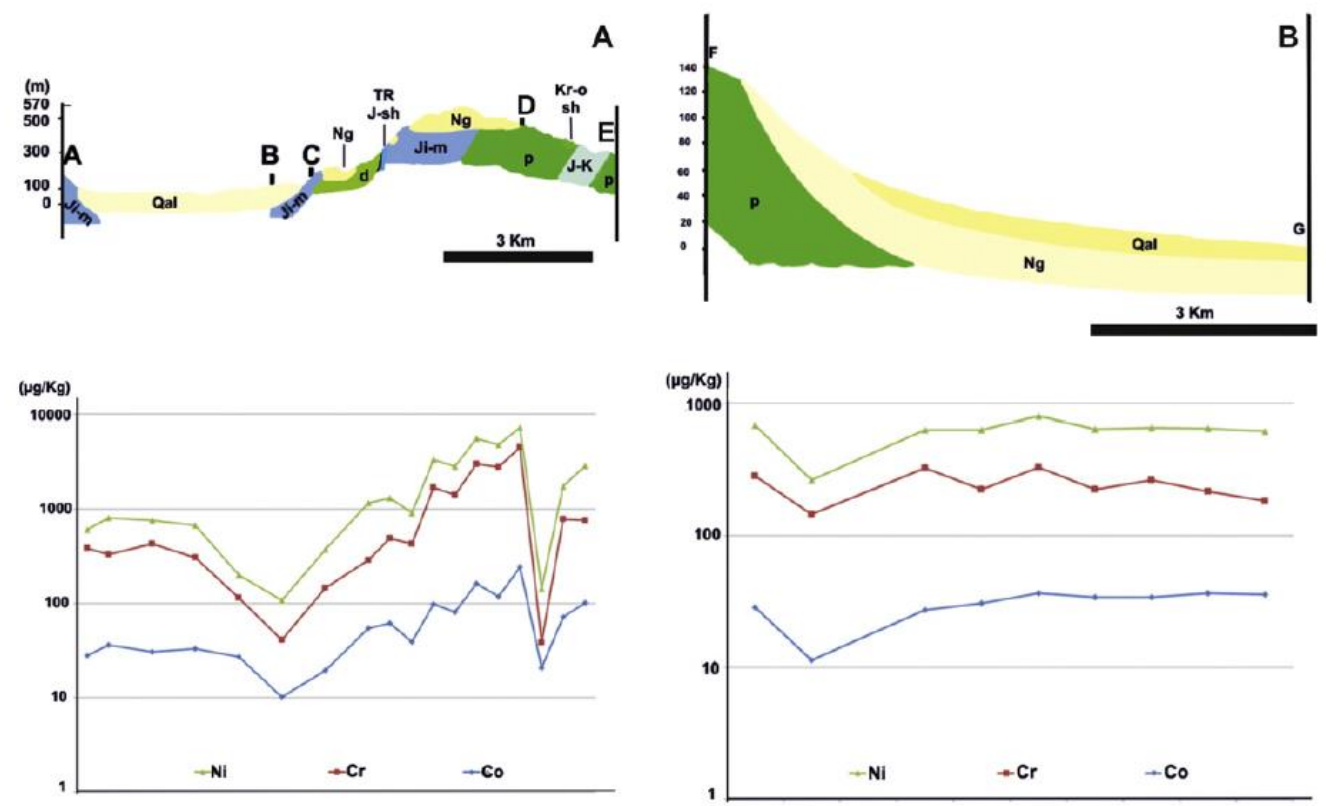

Figure 3 - Geological cross-sections of N-S (A) and W-E (B) direction and the related change of $\mathrm{Ni}, \mathrm{Cr}$ and $\mathrm{Co}$ concentrations in topsoil of Atalanti basin. Qal = Alluvial deposits, $\mathrm{Ng}=$ Neogene clastic deposits, $\mathrm{Kr}$-o $\mathbf{s h}=$ volcanic-clastic formation, $\mathbf{J i}-\mathrm{m}=$ limestone, $\mathrm{TR} \mathbf{J}$-sh $=$

Middle to lower Jurassic shale-chert formation with serpentinite, $\mathbf{p}=$ Peridotite, dunite, pyroxenperidotite, olivinite. (Kanellopoulos et al., 2015).

\subsection{Geochemical mapping of the Athens urban soil}

The continuously growing urban population globally has brought the attention of environmental geochemistry to the study of the environment within big cities of the word. The challenge in such studies is not only to unravel the complicated layering of the urban landscape and identify the natural or anthropogenic sources of harmful trace elements, but also to find effective ways to communicate the research results to policy and decision makers. Geochemical mapping has been proved to be a useful tool in this instance as it enables visualization of the produced data and understanding by nonexperts.

A systematic geochemical soil survey was performed across Greater Athens and Piraeus, Greece in 2012. Surface soil samples $(0-10 \mathrm{~cm})$ were collected from 238 sampling sites on a regular $1 \times 1 \mathrm{~km}$ grid and were digested by a $\mathrm{HNO} 3-\mathrm{HCl}-\mathrm{HClO} 4-\mathrm{HF}$ mixture (Argyraki and Kelepertzis, 2014). A combination of multivariate and Geographical Information System approaches were applied for discriminating natural from anthropogenic sources using 4 major elements, 9 trace metals, and 2 metalloids. Based on these analyses the lack of heavy industry in Athens was demonstrated by the influence of geology on the local soil chemistry with this accounting for $49 \%$ of the variability in the major elements, as well as $\mathrm{Cr}, \mathrm{Ni}, \mathrm{Co}$, and possibly As (median values of 102, 141, 16 and 24 $\mathrm{mg} \mathrm{kg}^{-1}$ respectively). The contribution to soil chemistry of classical urban contaminants including $\mathrm{Pb}, \mathrm{Cu}, \mathrm{Zn}, \mathrm{Sn}, \mathrm{Sb}$, and $\mathrm{Cd}$ (medians of 45, 39, 98, 3.6, 1.7 and $0.3 \mathrm{mg} \mathrm{kg}^{-1}$ respectively) was also observed (Fig. 4); significant correlations were identified between concentrations and urbanization indicators, including vehicular traffic, urban land use, population density, and timing of urbanization. 


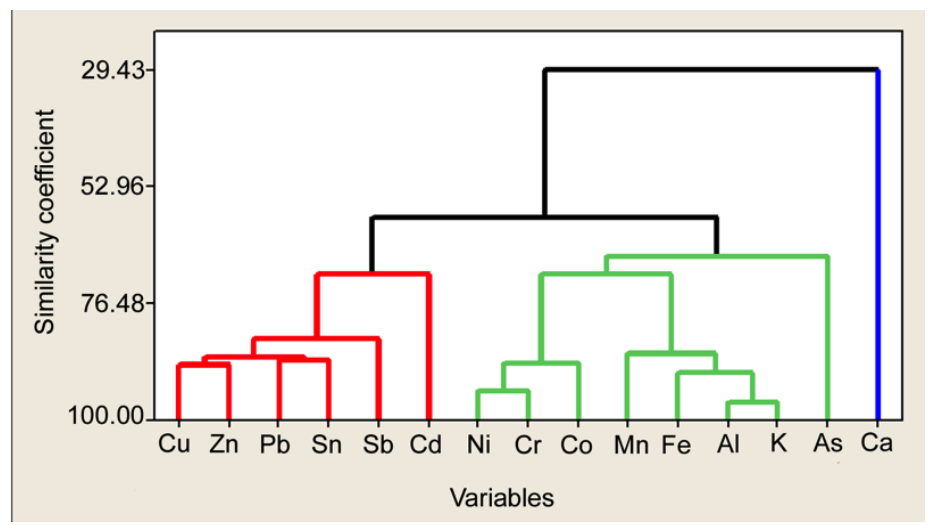

Figure 4- Dendrogram showing clustering of studied variables in the Athens soil into distinct groups of anthropogenic (red) and geogenic (green) elements (Argyraki and Kelepertzis, 2014).

A series of geochemical maps have been plotted enabling geochemical data interpretation. Class intervals on the geochemical maps were defined by natural breaks in the histograms of the original data, and elemental concentrations were plotted as circles with size increasing as a function of concentration. The interpolated surfaces using the Inverse Distance Weighting method (IDW) with a power of 2 were added in the background for better visual inspection of the spatial trends (red being higher and blue being lower) (Fig. 5). It must be noted that interpolated maps must be used with caution due to the variability between the sampling locations however, they provide the means so that individuals, municipalities, developers and organizations can make informed decisions about environmental risks. The baseline study has also guided further research into the speciation and environmental mobility of potentially harmful elements (Kelepertzis and Argyraki, 2015) as well as into potential risks of the evolving field of urban agriculture in Athens.

\subsection{Mineral amendments as binders of heavy metals in soil for the remediation of contaminated sites}

The immobilization of inorganic - non degradable contaminants in soil has been suggested as a sustainable remediation method aiming in breaking the pathway between the source and the receptor in the widely used 'source- pathway-receptor' risk assessment approach. Within this framework, various mineral-based amendments can be used in raw or modified form for inducing immobilization of inorganic contaminants in soil with different modes of molecular-scale sequestration.

Several laboratory scale and pilot field experiments have been set up to demonstrate the effectiveness of Greek minerals as binders of heavy metals in contaminated soil. For example the very high quality zeolitic tuff reduced the leaching of metals $(\mathrm{Cr}, \mathrm{Mn}, \mathrm{Ni}, \mathrm{Fe})$ by $91-100 \%$ in contaminated soil and sewage sludge (Filippidis et al., 2010; Filippidis et al., 2015). A series of batch and pilot scale applications of attapulgite clay, commercially produced by Geohellas S.A. in Grevena, Greece have demonstrated the effectiveness of this natural material as an amendment for the stabilization of metals in contaminated soil and sewage sludge (Zotiadis and Argyraki, 2013). The feasibility of applying attapulgite clay as a binder for in - situ stabilization of heavy metals in contaminated soil was demonstrated in a pilot scale experiment at Lavrion. The reduction of water leachable metal fraction of metals was determined as high as $17 \%$ for $\mathrm{Cu}, 50 \%$ for $\mathrm{Pb}, 45 \%$ for $\mathrm{Zn}$, $41 \%$ for $\mathrm{Cd}, 46 \%$ for $\mathrm{Ag}, 18 \%$ for As, $47 \%$ for $\mathrm{Mn}, 45 \%$ for Ba and $29 \%$ for Sb (Zotiadis et al., 2012). Results from this study proved that the presence of attapulgite clay reduced significantly the water leachable metal concentrations and subsequently the associated environmental risk to humans and biota. However, further research is needed in order to explore the mechanism that controls metal 
sorption by attapulgite clay. Once this is understood many more applications of this natural material will become possible.
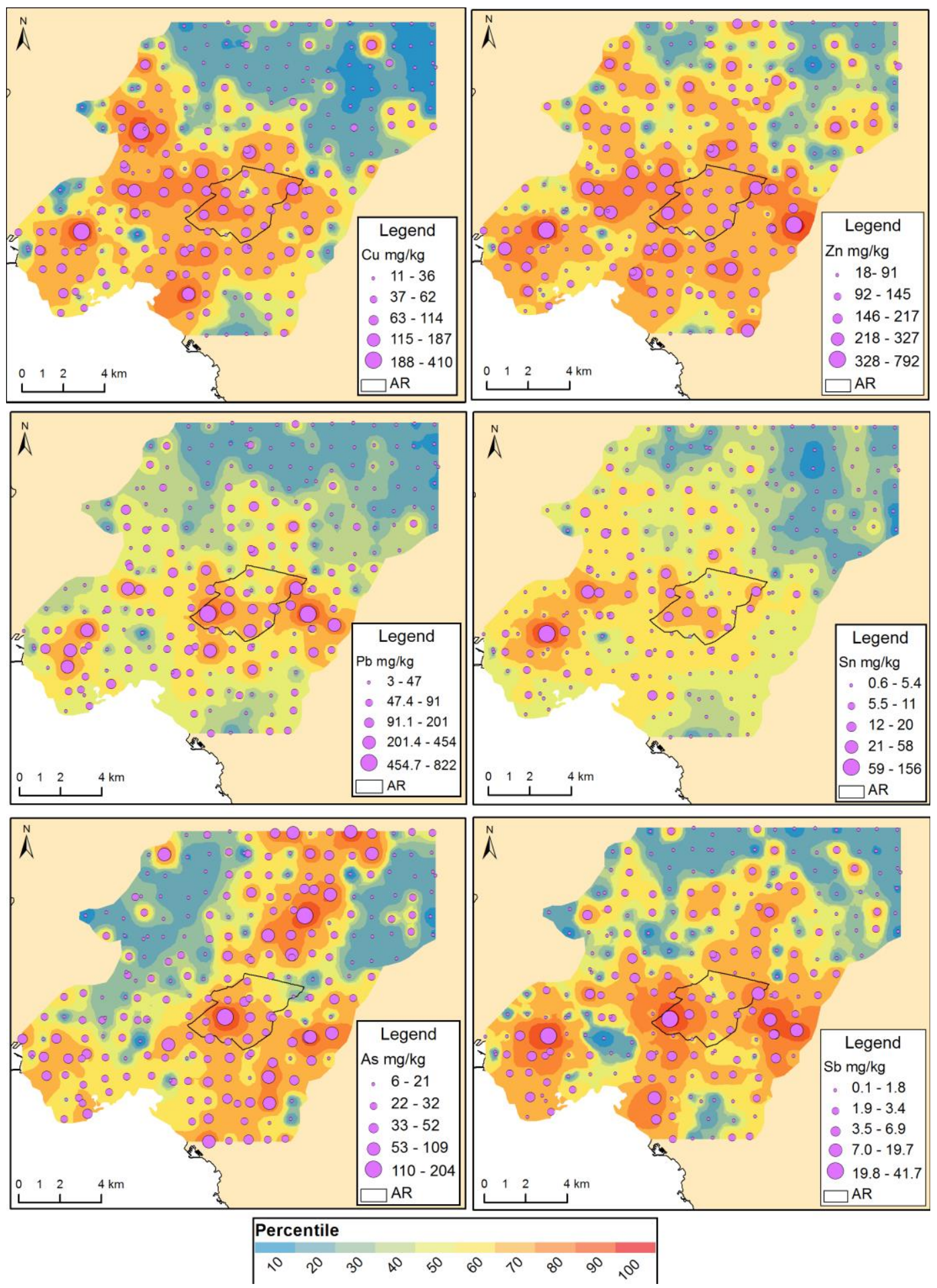

Figure 5 - Geochemical maps of selected elements in Athens soil. AR = Athens Ring. 
In a different study, Greek diasporic bauxite in raw form as well as after heat treatment at different temperatures $\left(105^{\circ} \mathrm{C}, 350^{\circ} \mathrm{C}\right.$ and $\left.450^{\circ} \mathrm{C}\right)$ was tested for its effectiveness in reducing the mobility of potentially harmful elements (PHE) in contaminated soil (Argyraki et al., 2015). A pot experiment was set up where calcined $\left(350^{\circ} \mathrm{C}\right)$ bauxite was mixed at different proportions $(0 \%, 1 \%, 2 \%, 4 \%$, $5 \%$ and $7 \%$ ) with contaminated soil from the sulfide ore mining area of Stratoni, north Greece. Total concentrations in soil have medians of $1000 \mathrm{mg} \mathrm{kg}^{-1} \mathrm{~Pb}, 712 \mathrm{mg} \mathrm{kg}^{-1} \mathrm{Zn}, 184 \mathrm{mg} \mathrm{kg}^{-1} \mathrm{Cu}, 6 \mathrm{mg} \mathrm{kg}$ ${ }^{1} \mathrm{Cd}, 296 \mathrm{mg} \mathrm{kg}^{-1} \mathrm{As}$ and $2900 \mathrm{mg} \mathrm{kg}^{-1} \mathrm{Mn}$. The effectiveness of bauxite amendment was evaluated by comparing leachable PHE concentrations of treated and untreated soil after a four week period of repeated cycles of wetting and mixing. Two leaching tests were used, one using deionized water (EN 12457-4) and another using a weak acid solution (TCLP). Also, a comparison of stabilization efficiency was carried out for the bauxite material used in the pot experiment $\left(350^{\circ} \mathrm{C}\right)$ and bauxite treated at different temperatures for a given rate of mixing (7\%). Both raw and calcined bauxite in a mixing proportion of $7 \%$ reduced leachable concentrations of the elements in comparison to the original soil. Samples that were mixed with activated bauxite $\left(105^{\circ} \mathrm{C}, 350^{\circ} \mathrm{C}\right)$ and raw bauxite showed similar results. The corresponding reduction of water leachable metal fraction of PHEs was determined as high as $75 \%$ for $\mathrm{Zn}, 66 \%$ for $\mathrm{Mn}, 55 \%$ for $\mathrm{Cd}, 51 \%$ for $\mathrm{Pb}, 44 \%$ for $\mathrm{Cu}$ and $41 \%$ for As. TCLP extractable concentrations remained relatively low for $\mathrm{Pb}$ (60\% reduction), $\mathrm{Zn}$ (30\% reduction) and As (28\% reduction). The maximum efficiency was observed by using treated bauxite at the temperature of $450^{\circ} \mathrm{C}$ with negligible water leachable concentrations after treatment. This difference in retention efficiency of elements is attributed to phase transitions that occur in Aloxyhydroxides and Fe-oxides/oxyhydoxides of bauxite when heated at higher temperatures. The above projects are characteristic examples of successful collaboration between the university and the research and development departments of companies involved in raw material production and processing.

\section{Opportunities and obstacles to development of environmental geochemistry in Greece}

Greece is characterized by an exceptionally interesting geological terrain. Laying at the edge of the European Continent, the Hellenic arc is geologically a very active area that provides the opportunity to observe and study a variety of earth system processes, ranging from typical manifestations of orogeny (including several types of ore deposits, active volcanoes and intense seismicity) to sensitive terrestrial, marine and coastal environments. As such, there are plenty "natural laboratories" providing opportunities to study environmental feedbacks and processes in action. Furthermore, the long human history of Greece, combined with the lack of Industrial Revolution legacy makes a very interesting case for studying the anthropogenic influence on the chemical environment through time.

A key obstacle in the scientific development is that despite its extremely rich natural capital, the country lags behind in regional baseline studies with respect to soil, sediment and water geochemistry. Systematic geochemical data are scarce and maps are only available for a few areas and at local scale. The Greek Geological Survey (IGME) in cooperation with earth science university departments across Greece could play a leading role in the development and publication of the so needed regional geochemical databases. There are at least four university departments that could contribute to this effort.

However, the task seems a particularly difficult one under the present economic situation. The economic and financial crisis has left a strong mark on research and innovation policies as it shifted the attention of government on macroeconomic stabilisation while research and innovation have become rather an 'orphan' in the highest political discussions (Izsak et al., 2013). During the crisis in Greece the severely reduced budget of the Public Investment Programme led to the limited absorption of the Structural Funds- almost the only available resource for funding research development and innovation projects. The low R\&D capacity and links between academia and 
industry may partially explain this outcome. Many Greek scientists living and working in Greece today agree that the ongoing damage to Greek scientific research is not solely due to austerity measures. According to Featherstone (2015), an ex- member of Greece's National Council for Research and Technology, political manipulation and institutional weakness are contributing to the situation. The above described situation as well as pre-existing obstacles such as the low remuneration levels for researchers and limited career progression prospects compared to the offer in other Western and Northern European countries is also the root to a severe brain drain phenomenon within the research community in Greece; geosciences are not an exception in this.

So, one wonders if there is a way out of the vicious circle and any chance for advancement in the field of environmental geochemistry in Greece at the moment. A first step might be for the Greek researchers to try avoid introversion and keep alive the links with the international scientific community. Networking opportunities are provided through the participation in national and international conferences and the building of interdisciplinary research groups with members of the international scientific community. Encouraging students and young researchers to join relevant national and international scientific societies may also foster fruitful future collaborations and access to research funds. Communication and translation of scientific results is also essential in order to demonstrate the impact of environmental geochemistry on socioeconomic aspects to non-experts involved in decision making including politicians and policy implementation bodies.

\section{Conclusions}

The impact of environmental geochemistry to sustainable development has been demonstrated through a number of research case studies. Surely, there are many more examples of significant completed and ongoing research in Greece in relevant topics (e.g. Petrotou et al., 2010; Kazakis et al., 2015). It is our duty as scientists to demonstrate the impact of our research outcomes and communicate the results to decision makers, especially under the current situation of economic crisis. Sustainable development involves quantifying the acceptable damage of the natural system and be able to recognize the limits to physical consumption. The building of a strategy and a plan of action towards this end at national level would benefit both our geo-scientific community and the so much needed development of the country.

\section{Acknowledgments}

The material presented in the case studies of this paper is derived to a great extent from the $\mathrm{PhD}$ research of Dr. Efstratios Kelepertzis and Dr. Christos Kanellopoulos as well as a number of research projects that were accomplished in recent years at the Laboratory of Economic Geology and Geochemistry, National and Kapodistrian University of Athens. The contribution of undergraduate and postgraduate students involved in research is greatly acknowledged. The companies Hellas Gold S.A., Edafomichaniki S.A., Geohellas S.A. and the John Latsis Public Benefit Foundation are acknowledged for providing funding of the related research projects. Prof. Anestis Filippidis is acknowledged for his useful contribution in the revision of the manuscript.

\section{References}

Argyraki, A. and Kelepertzis, E., 2012. Pre-mining environmental geochemical survey of a mineralised watershed in North Greece, Book of Abstracts of the $9^{\text {th }}$ International Symposium on Environmental Geochemistry, (ISBN: 978-972-789-365-2), Aveiro, Portugal, 15-21 July, $19 \mathrm{pp}$.

Argyraki, A. and Kelepertzis, E., 2014. Urban soil geochemistry in Athens, Greece: The importance of local geology in controlling the distribution of potentially harmful trace elements, Science of The Total Environment, 482-483, 366-377.

Argyraki, A., Boutsi, Z. and Zotiadis, V., 2015. Sustainable remediation of contaminated soil by using Greek diasporic bauxite, MedGeo2015: Book of Abstracts of the $6^{\text {th }}$ International 
Conference on Medical Geology, (ISBN: 978-972-789-449-9), In: Ferreira da Silva, E., et al., eds., Aveiro, UA Editora, 2015, XXIII, 156 pp.

Atkinson, A., 2008. The ISIS Agreement: How Sustainability Can Improve Organizational, Performance and Transform the World, Earthscan from Routledge, London, 336 pp.

Ball, J.W. and Izbicki, J.A., 2004. Occurrence of hexavalent chromium in ground water in the western Mojave Desert, California, Applied Geochemistry, 19, 1123-1135.

Dermatas, D., Vatseris, C., Panagiotakis, I. and Chrysochoou, M., 2012. Potential contribution of geogenic chromium in groundwater contamination of a Greek heavily industrialized area, Chemical Engineering Transactions, 28, AIDIC, Available online at: http://www.aidic.it/cet.

Economou-Eliopoulos, M., Megremi, I. and Vasilatos, Ch., 2011. Factors controlling the heterogeneous distribution of $\mathrm{Cr}(\mathrm{VI})$ in soil, plants and groundwater: Evidence from the Assopos basin, Greece, Chemie der Erde, 71, 39-52.

Featherstone, K., 2015. Greek politics stall research reforms, Nature, 518, 167.

Filippidis, A. 2010. Environmental, industrial and agricultural applications of Hellenic Natural Zeolite, Hellenic Journal of Geosciences, 45, 91-100.

Filippidis, A., Kantiranis, N., Papastergios, G. and Filippidis, S., 2015. Safe management of municipal wastewater and sludge by fixation of pollutants in very high quality HEU-type zeolitic tuff, Journal of Basic \& Applied Research Intern., 7(1), 1-8.

Izsak, K., Markianidou, P., Lukach, R. and Wastyn, A., 2013. The impact of the crisis on research and innovation policies, Study for the European Commission DG Research by Technopolis Group Belgium and Idea Consult.

Kanellopoulos, Ch., Argyraki, A. and Mitropoulos, P., 2015. Geochemistry of serpentine agricultural soil and associated groundwater chemistry and vegetation in the area of Atalanti, Greece, Journal of Geochemical Exploration, 158, 22-33.

Kazakis, N., Kantiranis, N., Voudouris, K.S., Mitrakas, M., Kaprara, E. and Pavlou, A., 2015. Geogenic $\mathrm{Cr}$ oxidation on the surface of mafic minerals and the hydrogeological conditions influencing hexavalent chromium concentrations in groundwater, Science of the Total Environment, 514, 224-238.

Kelepertzis, E. and Argyraki, A., 2015. Geochemical associations for evaluating the availability of potentially harmful elements in urban soils: Lessons learnt from Athens, Greece, Applied Geochemistry, 59, 63-73.

Kelepertzis, E., Argyraki, A. and Daftsis, E., 2012. Geochemical signature of surface water and stream sediments of a mineralized drainage basin at NE Chalkidiki, Greece: A pre-mining survey, Journal of Geochemical Exploration, 114, 70-81.

Ludden, J., Albarede, F. and Coleman, M., 2015. The impact of geochemistry, Elements, 11, 239-240.

Moraetis, D, Nikolaidis, N.P., Karatzas, G.P., Dokou, Z. and Kalogerakis N., 2012. Origin and mobility of hexavalent chromium in North-Eastern Attica, Greece, Applied Geochemistry, 27, 1170-1178.

Petrotou, A., Skordas, K., Papastergios, G. and Filippidis, A., 2010. Concentrations and bioavailability of potentially toxic elements in soils of an industrialised area of northwestern Greece, Fresenius Environmental Bulletin, 19(12), 2769-2776.

Sverdrup, H. and Ragnarsdottir, V., 2014. Natural Resources in a Planetary Perspective, European Association of Geochemistry, Geochemical Perspectives, 3(2), 129-341. Available online at: http://www.geochemicalperspectives.org/wp-content/uploads/2015/09/v3n2.pdf.

Zotiadis, V. and Argyraki, A., 2013. Development of innovative environmental applications of attapulgite clay, Bull. of the Geol. Soc. Greece, XLVII/2, 992-1001, Proc. of the $13^{\text {th }}$ International Congress, Chania, September.

Zotiadis, V., Argyraki, A. and Theologou, E., 2012. A Pilot Scale Application of Attapulgitic Clay for Stabilization of Toxic Elements in Contaminated Soil, Journal of Geotechnical and Geoenvironmental Engineering, 138, 633-637. 